\title{
Cogeneration and power export as factors of the Nogliki gas turbine power plant expansion
}

Georgiy Lachkov*, and Andrey Fedyaev, Melentiev Energy Systems Institute of Siberian Branch of the Russian Academy of Sciences, Irkutsk, Russia

\begin{abstract}
The paper focuses on the prospects for expansion of the Nogliki gas turbine power plant in terms of potential cogeneration of the Nogliki urban-type settlement of the Sakhalin region and power export from the Sakhalin Island to Japan. The state and problems of the Nogliki gas turbine power plant and heating systems of Nogliki are described. The alternatives of the Nogliki power plant expansion by upgrading with addition of hotwater heat recovery boilers and shift of part of thermal load of Nogliki from boiler plants to the gas turbine power plant. The excess power in this case is planned to be exported to Japan.
\end{abstract}

\section{Introduction}

Expansion of the Nogliki gas turbine power plant (GTPP) is urgent because of such important factors as ageing of main generating equipment and required upgrading of the power plant; expediency of improving the heating systems of Nogliki by cogeneration; prospect for power export to Japan; necessity of increasing the natural gas utilization efficiency.

Efficiency of cogeneration - centralized heat supply on the basis of combined production of electricity and heat at cogeneration plants- was justified long ago [1,2 and others.] and repeatedly confirmed by the authors as well [3-7 and others]. However, as concerns the Nogliki GTPP, this fact is not so categorical because of highly irregular power consumption. At the same time, the prospect for power export to Japan [8-13] expands opportunities for cogeneration of Nogliki on the basis of the gas turbine power plant making its electric load curve denser. In this case, shift of part of thermal load from boiler plants to GTPP will considerably decrease natural gas consumption for heat supply. This fact is of high priority from the standpoint of energy resource conservation and large-scale plans on natural gas export from Sakhalin to Japan and China as liquefied natural gas (LNG) $[14,15]$, and piped gas [16].

\section{Description of the studied object}

The Nogliki GTPP is situated approximately at a distance of $5 \mathrm{~km}$ southward of Nogliki. It was brought into service in 1999. The power plant was intended for substituting some part of the generating capacities of the Central load centre of the Sakhalin power

* Corresponding author: g.lachkov@isem.irk.ru 
system, which used solid and expensive imported liquid fuel, for meeting peak loads at power shortages in the power system and for removing limitations on power supply to consumers during the autumn and winter peak loads.

The main equipment of the power plant consists of four gas turbine units (GTU) manufactured by the "Zorya" - "Mashprojekt" firm (Nikolaev, Ukraine) with a rated capacity of $12 \mathrm{MW}$ each. At the beginning of 2017, the installed capacity of the power plant was $48 \mathrm{MW}$, the annual power generation - 213.5 million $\mathrm{kWh}$, the annual consumption of fuel (natural gas) -102 thousand tce. $\left(85.5\right.$ million $\left.\mathrm{m}^{3}\right)$.

The nearest consumers of power generated by the Nogliki GTPP are located in the settlements Nogliki, Val, Katangli, Goryachie Klyuchi of the Nogliki district. The power unused in the district is transmitted to the network of PJSC "Sakhalinenergo".

The power plant is used to cover peak loads - the load curve irregularity factor is $44 \%$.

At present, the Nogliki GTPP operates without utilization of the heat of flue gases. Therefore, the performance criteria for main equipment of the power plant are low: the efficiency of gas turbine units is less than $24 \%$; the specific fuel consumption -499.4 gce $/ \mathrm{kWh}$. With an installed resource of the equipment of 45,000 hours, the actual running hours of gas turbine units ranges from 50,000 to 100,000 . In addition, the power plant has a substantial impact on the environment - the temperature of the exhaust gases emitted into the atmosphere is over $320-350^{\circ} \mathrm{C}$, and the annual emissions of nitrogen oxides are about 250 tons.

Table 1. Main technical and economic indicators of the Nogliki GTPP ${ }^{1}$

\begin{tabular}{|c|c|c|c|c|}
\hline Indicator & $\mathbf{2 0 0 5}$ & $\mathbf{2 0 1 0}$ & $\mathbf{2 0 1 5}$ & $\mathbf{2 0 2 0}$ \\
\hline Power generation, million $\mathrm{kWh}$ & 197 & 222 & 222 & 213 \\
\hline Supply to the system, million $\mathrm{kWh}$ & 190 & 212 & 213 & 204 \\
\hline Installed capacity utilization time, h & 4110 & 4626 & 4629 & 4447 \\
\hline Annual fuel consumption, thou-sand tce & 93.3 & 111.6 & 95.0 & 102.0 \\
\hline Specific fuel consumption, gce./kWh & 490.0 & 519.7 & 440.6 & 499.4 \\
\hline
\end{tabular}

Heat supply of Nogliki is based on the local systems of 20 municipal and departmental boiler plants. The heating systems are closed with a de-sign temperature graph of $95 / 70{ }^{\circ} \mathrm{C}$. The total installed capacity of boiler plants amounts to $75 \mathrm{Gcal} / \mathrm{h}$, the connected heat load is $36 \mathrm{Gcal} / \mathrm{h}$, the total annual fuel demand is 24 thousand tce. The degree of boiler wear is high (about $80 \%$ ), the design efficiency is no higher than $70 \%$, the average specific fuel consumption is $200 \mathrm{kgce} / \mathrm{Gcal}$.

All boiler plants burn natural gas and are connected to the gas pipeline networks of OJSC "Sakhalinoblgaz" with a pressure of $0.3 \mathrm{MPa}$. Practically all boiler plants in the settlement operate only during the heating period. Hot water supply of existing residential buildings is based primarily on the wall geysers of 16 and $24 \mathrm{~kW}$ (thermal). The centralized hot water supply networks in the settlement are almost absent. Only several residential buildings are supplied with hot water from boiler plants.

The total length of heat networks is about $30 \mathrm{~km}$. Most of the pipelines are laid underground in inaccessible ducts and about $6.5 \mathrm{~km}$ of pipelines are laid above ground. The maximum diameter of pipelines is $325 \mathrm{~mm}$, the average one $-127 \mathrm{~mm}$. Wear of the pipelines reaches $70 \%$, their essential corrosion is caused by the absent water purification in the majority of boiler plants. The poor state of thermal insulation and the wear of pipelines lead to high heat losses in the networks (from 18 to $35 \%$ ) and hence, to excessive fuel consumption.

\footnotetext{
${ }^{1}$ According to the data of the Federal Statistics Service of RF
} 


\section{Analysis of expansion alternatives}

The low efficiency indices of the Nogliki GTPP are due primarily to the facts that the design concepts on the settlement cogeneration using the heat of flue gases of gas turbine units were not realized, and the moral and physical ageing of main equipment installed at the power plant were considerable. The service life of all four gas turbine units reached 100 $\%$. Therefore, the chief direction for expansion of the Nogliki GTPP is believed to consist in replacement of the worn-out gas turbine units by the up-to-date high-performance turbines and arrangement of cogeneration by installing hot-water heat recovery boilers operating on energy of exhaust gases of gas turbine units for heat production and supply to the heating system of Nogliki.

As far as the capacity and structure of main equipment at the reconstructed Nogliki GTPP depended on its thermal load, it had to be deter-mined first. For this purpose several alternatives of heat supply to consumers of Nogliki were proposed (Fig. 1). They assumed the use of combined production of electricity and heat by the Nogliki GTPP with different connected thermal loads and laying of main heat networks from the plant to:

- boiler plant-10 (the thermal load of GTPP - $5.9 \mathrm{Gcal} / \mathrm{h}$ ) - alternative A;

- boiler plan-12 (the thermal load of GTPP - $15.5 \mathrm{Gcal} / \mathrm{h}$ ) - alternative B;

- boiler plant-16 (the thermal load of GTPP - $24.3 \mathrm{Gcal} / \mathrm{h}$ ) - alternative C.

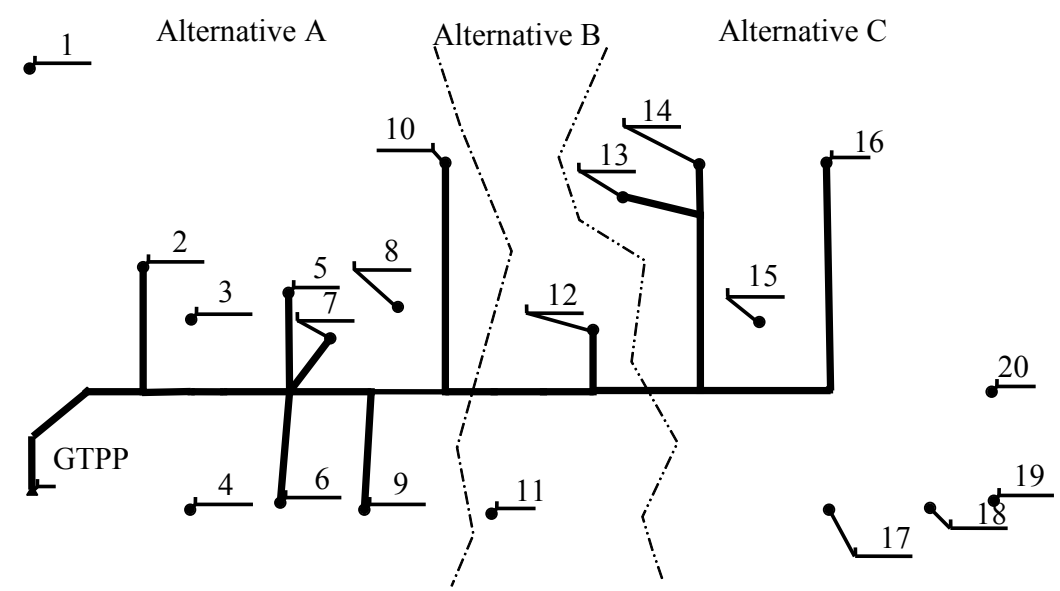

Fig. 1. Conventional scheme of the heating system for the Nogliki settlement (1-20 - numbers of boiler plants).

It is suggested that the heat supply from Nogliki GTPP be arranged by the two-loop cycle with the network heat points, which are connected to two independent loops. The heat carrier parameters in the primary loop from GTPP will be $130 / 70{ }^{\circ} \mathrm{C}$, in the secondary loops after the network heat points they will be $95 / 70{ }^{\circ} \mathrm{C}$. The independent loops are supposed to increase the stability and control level of the heat supply system.

In this case at the sites of removed boiler plants it is planned to construct heat points with heat exchangers for switching to the heat supply system with temperature curves of $95 / 70{ }^{\circ} \mathrm{C}$, which will not to change the structure of existing heat networks.

As a result of technical and economic calculations the following heat supply alternative for Nogliki was chosen on the basis of the current electric load curves of GTPP and the connected thermal load curves (the payback period -8 years, the internal rate of return $19.5 \%$ ): 
1. The main heat networks are laid from GTPP to the existing boiler plant12 (the network temperature curve $-130 / 70{ }^{\circ} \mathrm{C}$, the main pipeline diameter $-300 \mathrm{~mm}$, the number of central heat points -7 ).

2. The consumers of the following boiler plants to be removed from operation are connected to GTPP: $2,5,6,7,9,10,12$ (the total thermal load $-15.5 \mathrm{Gcal} / \mathrm{h}$ ).

3 . For the reliability reason, two new gas turbine units of $12 \mathrm{MW}$ each with addition of hot-water heat recovery boilers with a heat output of $16 \mathrm{Gcal} / \mathrm{h}$ each are installed at GTPP.

Thus, in the considered alternative (with the connected thermal load equal to 15.5 $\mathrm{Gcal} / \mathrm{h}$ ) the installed heat output of the Nogliki GTPP will amount to $32 \mathrm{Gcal} / \mathrm{h}$. The installed electric capacity of GTPP is determined by its maximum electric load. According to the Scheme and Program of electric power industry development in the Sakhalin region the maximum load of the Nogliki GTPP will reach $46 \mathrm{MW}$ in the years to come. Hence, it will be necessary to install at the plant no less than four gas turbine units of $12 \mathrm{MW}$ each (two of which are with hot-water heat recovery boilers).

The worn-out Ukrainian gas turbine units at the Nogliki power plant can be replaced, for example, by the domestic gas turbines of similar capacity that are manufactured by JSC "Aviadvigatel" (Perm city) (Table 2) with addition of the domestic hot-water heat recovery boilers with an output of about $6 \mathrm{Gcal} / \mathrm{h}$ that are manufactured by "Belenrgomash" LLC (Belgorod city) (Table 3).

Table 2. Main performance of the gas turbine unit GTP-12PG-2 manufactured by SC "Aviadvigatel"

\begin{tabular}{|c|c|}
\hline Electric capacity, MW & 12.3 \\
\hline Heat output, Gcal/h & 16.6 \\
\hline Electric efficiency, $\%$ & 32.6 \\
\hline Overall efficiency, $\%$ & 83.7 \\
\hline Design life time, thousand $\mathrm{h}$ & 100 \\
\hline Specific fuel consumption, gce $/ \mathrm{kWh}$ & 228 \\
\hline
\end{tabular}

Table 3. Main performance of the hot-water heat recovery boiler KUV-17 manufactured by "Belenrgomash" LLC

\begin{tabular}{|c|c|}
\hline Rated heat output, $\mathrm{MW}(\mathrm{Gcal} / \mathrm{h})$ & 19.2 \\
\hline Design water pressure at boiler outlet, $\mathrm{MPa}\left(\mathrm{kgf} / \mathrm{cm}^{2}\right)$ & $2.5(25)$ \\
\hline Water temperature at boiler outlet, ${ }^{\circ} \mathrm{C}$ & 150 \\
\hline Water temperature at boiler inlet, ${ }^{\circ} \mathrm{C}$ & 70 \\
\hline Volume of cooled gases, $\mathrm{kg} / \mathrm{s}$ & 57 \\
\hline Temperature of flue gases at boiler inlet, ${ }^{\circ} \mathrm{C}$ & 471 \\
\hline Temperature of flue gases at boiler outlet, ${ }^{\circ} \mathrm{C}$ & 113 \\
\hline
\end{tabular}

Increase in the cogeneration level of Nogliki (with piping of the main heat networks from GTPP to boiler 1 and addition of the hot-water heat recovery boiler to the additional gas turbine unit) is hindered by the irregularity of electric load of the Nogliki GTPP. Arrangement of power export can contribute to solution of this problem.

The projects on construction of the power bridge Sakhalin - Japan [8-10] (Table 4) and formation of the Asian energy supergrid open the way for export of the excess power at the Nogliki GTPP [9-13 and others].

The power bridge Sakhalin - Hokkaido must be included in the Asian energy superpool. Power to Japan will be supplied from the Nogliki GTPP, Sakhalin CPP, Sakhalin CPP-2 under construction and South-Sakhalin CP. In the future, the Komsomolsk CPs 1-3, Amur $\mathrm{CP}$, Maisk CPP, which are situated onshore, can also be involved [10]. 
Table 4. Predicted parameters of the power bridge Sakhalin - Japan ${ }^{2}$

\begin{tabular}{|c|c|c|c|c|}
\hline Directions of electric ties & $\begin{array}{c}\text { Length*, } \\
\mathbf{k m}\end{array}$ & $\begin{array}{c}\text { Voltage, } \\
\mathbf{k V}\end{array}$ & $\begin{array}{c}\text { Transfer } \\
\text { capability, } \\
\text { GW }\end{array}$ & $\begin{array}{c}\text { Transmitted } \\
\text { power, } \\
\text { TWh }\end{array}$ \\
\hline Sakhalin-Hokkaido-Honshu & $1850 / 1400$ & \pm 600 & 4 & 24 \\
\hline Sakhalin-Hokkaido & $500 / 50$ & \pm 400 & 4 & 24 \\
\hline
\end{tabular}

* The total length is in the numerator, the submarine cable length is in the denominator

With commissioning of the additional $12 \mathrm{MW}$ gas turbine unit with the $16 \mathrm{Gcal} / \mathrm{h}$ hotwater heat recovery boiler the heat output of the Nogliki GTPP will reach $48 \mathrm{Gcal} / \mathrm{h}$, and the electric capacity - $60 \mathrm{MW}$. The in-stalled capacity of the power plant can further be increased by installation of additional gas turbine units depending on the export requirements.

More effective natural gas utilization owing to combined production of heat and electricity is an important factor for shifting of thermal load from boiler plants to GTPP.

The calculations show that shifting of $15.5 \mathrm{Gcal} / \mathrm{h}$ of thermal load from boiler plants to the Nogliki GTPP makes it possible to produce above 58.4 thousand Gcal of thermal energy virtually without fuel consumption and hence, to provide an annual gas saving of about 11.7 thousand tce $\left(10\right.$ million $\left.\mathrm{m}^{3}\right)$, and shifting of $24.3 \mathrm{Gcal} / \mathrm{h}$ of thermal energy from boiler plants to GTPP allows us to produce above 91.6 thousand Gcal of thermal energy and save 18.3 thousand tce. $\left(15.5\right.$ million $\left.\mathrm{m}^{3}\right)$ of natural gas without fuel consumption.

\section{Conclusions}

The results of the technical and economic calculations have showed the effectiveness of the project on the Nogliki GTPP upgrading by installation of new gas turbine units and addition of hot-water heat recovery boilers with partial cogeneration of Nogliki in the Sakhalin region owing to utilization of the heat of flue gases.

The considered cogeneration alternative of Nogliki provides limited facilities for operation of the Nogliki GTPP according to the thermal and electric load curves because of irregular power consumption.

Power export from the Sakhalin Island to Japan will make the electric load curve of the Nogliki GTPP denser, and hence, will increase the thermal load of the power plant and the cogeneration level of Nogliki.

Effectiveness of natural gas utilization for heat supply of the settlement can also be increased owing to cogeneration. The annual natural gas saving can reach from 11.7 thousand tce $\left(10\right.$ million $\left.\mathrm{m}^{3}\right)$ to 18.3 thousand tce $\left(15.5\right.$ million $\left.\mathrm{m}^{3}\right)$ depending on the cogeneration level.

\section{Acknowledgements}

The study was carried out within the framework of the scientific project III.17.6.1 of the fundamental research program of SB RAS, registration No. AAAA-A17-117030310445-9

\section{References}

1. E.Ya. Sokolov. Cogeneration and heat networks. M.: MEI, 472 p. (1999).

\footnotetext{
${ }^{2}$ According to the data of [9]
} 
2. L.S. Khrilev Basic lines and effectiveness of cogeneration development. Teploenergetika, No. 4, pp. 2-12 (1998).

3. V.I. Dlugoselsky, A.S.Zemtsov. Utilization efficiency of gas and com-bined cycle gas turbine technologies in cogeneration. Teploenergetika, No. 12, pp. 3-6 (2000).

4. G.G. Lachkov, A.V. Fedyaev, Yu.E. Kolegov, S.V. Yakshin. Effec-tiveness of using gas mini-cogeneration plants in an energy shortage region. Vestnik IrGTU, No. 9, pp.146-151 (2015).

5. G.G. Lachkov, A.V. Fedyaev. Improvement of regional energy supply systems on the basis of distributed cogeneration. Vestnik IrGTU, No. 11, pp.165-170 (2015).

6. Kolegov Yu.E., Fedyaev A.V. Specific features of heat supply scheme development for cities with gas supply to regions. Teploenergetika, No. 12, P. 55-60 (2009).

7. G.G. Lachkov. Improvement of energy efficiency of the power supply system in Salekhard on the basis of cogeneration. Vestnik of IrGTU, No. 10, pp.135-141 (2016).

8. Koshcheev L.A., Kucherov Yu.N., Sakemi T., Natori K. Russian- Japan Power Bridge // Proc. of the 2nd Intern. Conf. on Energy Integration in Northeast Asia. Irkutsk, Russia, (Sept. 21-22, 2000), pp. 44-52.

9. S.V. Podkovalnikov, V.A. Savelyev, L.Yu. Chudinova. Prospects for power cooperation of Russia and Northeast Asia countries// Problems of forecasting, No. 4, pp.118-130 (2015).

10. Rosseti started the work on implementation of the project of the Asian energy superpool. Available at: http://neftegaz.ru/news/view/153126-Rosseti-nachali-rabotupo-realizatsii-proekta-Aziatskogo-energeticheskogo-superkoltsa (20.09.2017).

11. The idea of interconnecting energy systems of Russian and APR coun-tries has been revived. Available at: https://rg.ru/2017/09/05/vozrozhdena-ideia-obedineniiaenergosistem-rossii-i-stran-atr.html (07.09.2017).

12. Park D.-W., Kim H.-Y., Yoon J.-Y., Voropai N.I., Belyaev L.S., Podkovalnikov S.V. Analysis of Scenarios for Potential Power System Interconnections in Northeast Asia. Proceedings of the 4th Interna-tional Conference "Asian Energy Cooperation: Interstate Infrastructure and Energy Markets”, Irkutsk, Energy Systems Institute, pp. 67-73 (2004).

13. Current Status and Prospects for the Development of Interstate Electric Ties and Power Pools: Lessons for Northeast Asia / L.S. Belyaev, L.Yu. Chudinova, S.V. Podkovalnikov, V.A. Savelyev. Northeast Asia Energy Focus, Vol.5, No. 1, pp. 17-27 (2008).

14. Sakhalin Energy schedules construction of the III stage of LNG plant for 3-4 years. Available at: http://ria.ru/economy/20150629/1100752019.html (08.02.2018).

15. "Vladivostok LNG" scales down. Available at: https://www.kommersant.ru/doc/3342085 (08.02.2018).

16. Gas to China: "Power of Siberia", French gold seamstresses and Yamal LNG. Available at: https://ria.ru/east_economy/20151229/1350927405.html (08.02.2018). 